\title{
Evaluation of Relationship Between Uric Acid and CRP, RDW, and MPV as Cardiovascular Risk Factors in Patients with Hypertension
}

Yasemin Aker KARAGÖZ², İrfan ŞAHIN'1 , Ferdi KARAGÖZ², Dede ŞiT ${ }^{1}$

${ }^{1}$ Clinic of Internal Diseases - Nephrology, and Cardiology, Bağclar Training and Research Hospital, İstanbul, Turkey

${ }^{2}$ Clinic of Family Practice, Sögüt State Hospital, Bilecik, Turkey

${ }^{3}$ Clinic of Internal Diseases, Bilecik State Hospital, Bilecik, Turkey

\section{ABSTRACT}

Objective: Many factors that are associated with both clinical outcomes and pathogenesis of disease in cases of essential hypertension have been reported. One of these is uric acid. In this study, we aimed to investigate the relationship between serum and spot urine uric acid levels and red blood cell distribution width (RDW), mean platelet volume (MPV), and C-reactive protein (CRP) levels in patients with essential hypertension.

Methods: Sixty-two patients with essential hypertension were enrolled in the study between January 01, 2013 and December 31, 2013. The presence of cardiovascular disease was assessed by echocardiography, coronary angiography, and stress test. The patients were divided into two groups according to the absence (group 1) or presence (group 2) of cardiovascular complications. Data were collected for serum and spot urine uric acid levels, serum CRP levels, MPV, and RDW and were compared between the two groups.

Results: Cardiovascular complications were determined in 23 patients (37.1\%). In groups 1 and 2, the CRP level was 4.89 and 3.64, RDW was 13.8 and 13.5 , serum uric acid level was $5.57 \pm 1.23$ and $5.33 \pm 0.8$, spot urine uric acid level was $65.13 \pm 29.11$ and $61.94 \pm 18.13$, and MPV was 7.7 and 7.2, respectively. A significant difference was not found between the two groups in terms of serum and spot urine uric acid levels, serum CRP levels, MPV, and RDW ( $>0.05$ ). In group 2, there was a significant negative correlation between the glomerular filtration rate and RDW and between RDW and MPV and positive correlation between CRP levels and RDW $(\mathrm{p}<0.01, \mathrm{p}<0.05$, and $\mathrm{p}<0.05$, respectively).

Conclusions: Serum and spot urine uric acid levels, serum CRP levels, MPV, and RDW cannot predict the development of cardiovascular disease in patients with essential hypertension.

Keywords: Hypertension, uric acid, CRP, MPW, RDW

\section{Introduction}

The close relationship between uric acid and hypertension (HT) has been demonstrated both in experimental models and in clinical studies $(1,2)$. It has been reported that although hyperuricemia is a known risk factor for HT, early treatment of hyperuricemia can help control blood pressure more easily and prevent cardiovascular complications secondary to HT $(3,4)$.

Both HT and hyperuricemia are well-known risk factors for premature cardiovascular diseases $(5,6)$. The relationship between the levels of serum uric acid, C-reactive protein (CRP), mean platelet volume (MPV), and red blood cell distribution width (RDW) and cardiovascular diseases has been revealed in various studies (6-14). Many studies have shown that markers such as uric acid, high-sensitivity CRP (hsCRP), and RDW can be effective in predicting targeted organ damage.

In this study, we aimed to find the predictive value for the early detection of cardiovascular diseases using serum and spot urine uric acid, RDW, MPV, and CRP in hypertensive patients. 


\section{Methods}

\section{Patients}

The study included patients who applied to the outpatient clinic of Internal Diseases and Cardiology between January 01, 2013, and December 31, 2013. The patients diagnosed with diabetes mellitus, heart failure, chronic kidney disease, paralysis, and chronic obstructive pulmonary disease were excluded from the study. After receiving approval from the Local Ethics Committee, 62 patients who agreed to participate in the study and signed the written informed consent form were enrolled. The patients were divided into two groups as those developing and not developing cardiovascular complications according to the results of echocardiography, stress test, and angiography.

The following were determined to be the cardiovascular complications: diastolic dysfunction, systolic dysfunction, $\geq 50 \%$ coronary stenosis, and low ejection fraction. The patients with the absence (group 1) and presence (group 2) of cardiovascular complications were identified. Laboratory parameters, blood pressure values, and length of HT were compared among the patients included in the study.

\section{Samples}

Uric acid parameters of the patients were studied with $A D$ VIA device using the enzymatic uricase/peroxidase method; MPV and RDW parameters were studied with ADVIA 2120i device and CRP parameters with ADVIA device using latexenhanced immunoturbidimetric method. Glomerular filtration rate (GFR) was calculated using modification of diet in renal disease $(\mathrm{MDRD})$ formula $(\mathrm{GFR}=186$ ' serum creatinine $-1.154^{\prime}$ age-0.203' gender 'race) (15).

\section{Statistical analysis}

While evaluating the data obtained from the study, IBM Statistical for Package Social Sciences (SPSS IBM Corp; Armonk, NY, USA) Statistics 22.0 software was used for statistical analysis. Descriptive statistical methods (mean and standard deviation) were employed. In the between-group comparisons of quantitative data, Student's t-test was used for comparing normally distributed parameters. Non-normally distributed data were compared using Mann-Whitney U test. On the other hand, continuity correction (Yates) test and Fisher's exact test were employed for comparing the qualitative data. Diagnostic scanning tests were utilized in the calculation of specificity and sensitivity. The significance was evaluated at the level of $\mathrm{p}<0.05$.

\section{Results}

Of all the patients included in our study, 39 (62.9\%) (group 1) had no cardiovascular complication, whereas 23 (37.1\%) (group 2) had the complications. The mean age of the patients was $51.09 \pm 8.62(31-69)$ years. While the mean age was $50.15 \pm 8.13$ years in Group 1, it was 52.69 \pm 9.36 years in Group 2 , and no statistically significant difference was found between the groups in terms of mean ages $(p>0.05)$. The mean systolic
Table 1. Blood pressure and demographic features of patients

\begin{tabular}{|c|c|c|c|c|}
\hline & $\begin{array}{c}\text { Group } 1 \\
(n=39)\end{array}$ & $\begin{array}{c}\text { Group } 2 \\
(n=23)\end{array}$ & $\begin{array}{l}\text { Total } \\
(n=62)\end{array}$ & $\mathbf{p}$ \\
\hline${ }^{1}$ Age (years) & $50.15 \pm 8.13$ & $52.69 \pm 9.36$ & $51.09 \pm 8.62$ & 0.266 \\
\hline${ }^{2} \mathrm{SBP}(\mathrm{mmHg})$ & 140 & 150 & 140 & $0.042 *$ \\
\hline${ }^{2} \mathrm{DBP}(\mathrm{mmHg})$ & 90 & 90 & 90 & $0.038 *$ \\
\hline${ }^{2} \mathrm{BMI}\left(\mathrm{kg} / \mathrm{m}^{2}\right)$ & 30.04 & 32.18 & 30.42 & 0.166 \\
\hline \multicolumn{5}{|l|}{${ }^{3}$ Gender; n (\%) } \\
\hline Male & $13(33.3)$ & $7(30.4)$ & $20(32.3)$ & 31.000 \\
\hline Female & $26(66.7)$ & $16(69.6)$ & $42(67.7)$ & \\
\hline
\end{tabular}

${ }^{1}$ Student's t-test [M $\pm S D$ (mean \pm standard deviation)]; ${ }^{2}$ Mann-Whitney $U$ test (median); ${ }^{3}$ Continuity Correction (Yates) test; * $\mathrm{p}<0.05$; SBP: systolic blood pressure; DBP: diastolic blood pressure; BMI: body mass index

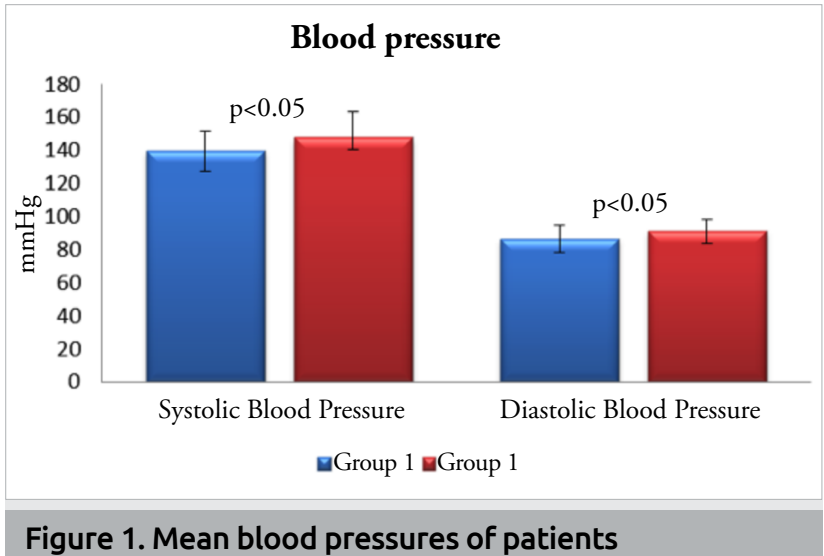

blood pressure (SBP) in Group $2(150 \mathrm{mmHg})$ was significantly higher than that in Group $1(140 \mathrm{mmHg})(\mathrm{p}<0.05)$. The mean diastolic blood pressure (DBP) in Group $2[90 \mathrm{mmHg}$ (91.3 \pm 7.42$)]$ was significantly higher than that in Group 1 [90 $\mathrm{mmHg}(86.54 \pm 8.36)](\mathrm{p}<0.05)$ (Table 1, Figure 1).

While there was a statistically significant difference between the groups with regard to cholesterol and triglyceride levels, no difference was detected with regard to low-density lipoprotein (LDL) and high-density lipoprotein (HDL) cholesterol levels $(\mathrm{p}<0.05$ and $\mathrm{p}>0.05$, respectively).

The mean CRP level was $4.89 \mathrm{mg} / \mathrm{L}$ in Group 1 and 3.64 $\mathrm{mg} / \mathrm{L}$ in Group 2. The mean RDW level was $13.8 \mathrm{RU}$ in Group 1 and 13.5 RU in Group 2. The mean serum and spot urine uric acid levels of Group 1 were $5.57 \pm 1.23 \mathrm{mg} / \mathrm{dL}$ and $65.13 \pm 29.11 \mathrm{mg} / \mathrm{dL}$, respectively; for Group 2, these values were $5.33 \pm 0.8 \mathrm{mg} / \mathrm{dL}$ and $61.94 \pm 18.13 \mathrm{mg} / \mathrm{dL}$, respectively. A statistically significant difference was not found between the groups for all parameters $(\mathrm{p}>0.05)$ (Table 2).

A comparison of normal and abnormal values of CRP, uric acid, MPV, and RDW is presented in Table 3. The measurement results of sensitivity of CRP, uric acid, MPV, and RDW values in the prediction of the disease are presented in Table 4. Sensitivity and specificity were calculated based on normal 
Table 2. Patients' laboratory findings and distribution according to groups

\begin{tabular}{|c|c|c|c|c|}
\hline & Group 1 (n=39) & Group 2 (n=23) & Total $(n=62)$ & $\mathbf{p}$ \\
\hline${ }^{2}$ Glucose & 96 & 99 & 97.5 & 0.669 \\
\hline 2Insulin & 15.63 & 15.44 & 15.54 & 0.402 \\
\hline${ }^{2} \mathrm{HOMA}-\mathrm{IR}$ & 3.26 & 3.58 & 3.48 & 0.410 \\
\hline${ }^{2}$ Cholesterol & 195 & 207 & 200.5 & $0.036^{*}$ \\
\hline${ }^{2} \mathrm{LDL}$ & 124 & 127 & 124 & 0.092 \\
\hline${ }^{2}$ Triglyceride & 134 & 171 & 143.5 & $0.020 *$ \\
\hline${ }^{2} \mathrm{HDL}$ & 48 & 48.6 & 48.3 & 0.657 \\
\hline${ }^{2} \mathrm{CRP}$ & 4.89 & 3.64 & 4.48 & 0.884 \\
\hline${ }^{2} W B C$ & 7.56 & 7.31 & 7.42 & 0.531 \\
\hline${ }^{2} \mathrm{RDW}$ & 13.8 & 13.5 & 13.8 & 0.232 \\
\hline${ }^{2} \mathrm{MPV}$ & 7.7 & 7.2 & 7.5 & 0.439 \\
\hline${ }^{2} \mathrm{~T} 4$ & 1.11 & 1.13 & 1.12 & 0.878 \\
\hline${ }^{1} \mathrm{HbA} 1 \mathrm{c}$ & $5.63 \pm 0.44$ & $5.64 \pm 0.4$ & $5.63 \pm 0.42$ & 0.941 \\
\hline${ }^{1}$ Creatinine & $0.78 \pm 0.17$ & $0.84 \pm 0.17$ & $0.80 \pm 0.17$ & 0.223 \\
\hline${ }^{1} \mathrm{GFR}$ & $95.67 \pm 15.09$ & $88.56 \pm 15.34$ & $93.03 \pm 15.45$ & 0.080 \\
\hline${ }^{1}$ Sodium & $140.92 \pm 2.52$ & $141.17 \pm 2.53$ & $141.01 \pm 2.51$ & 0.707 \\
\hline${ }^{1}$ Potassium & $4.33 \pm 0.4$ & $4.52 \pm 0.46$ & $4.40 \pm 0.43$ & 0.101 \\
\hline${ }^{1}$ Calcium & $9.67 \pm 0.46$ & $9.88 \pm 0.36$ & $9.75 \pm 0.43$ & 0.068 \\
\hline${ }^{1}$ Magnesium & $2.05 \pm 0.2$ & $2.12 \pm 0.26$ & $9.75 \pm 0.23$ & 0.226 \\
\hline${ }^{1}$ Blood uric acid & $5.57 \pm 1.23$ & $5.33 \pm 0.8$ & $5.49 \pm 1.09$ & 0.356 \\
\hline${ }^{1}$ Spot urine uric acid & $65.13 \pm 29.11$ & $61.94 \pm 18.13$ & $63.94 \pm 25.47$ & 0.598 \\
\hline${ }^{1}$ Hemoglobin & $13.43 \pm 1.72$ & $13.85 \pm 1.45$ & $13.58 \pm 1.63$ & 0.325 \\
\hline${ }^{1}$ Platelet & $267.87 \pm 64.79$ & $278.07 \pm 72.49$ & $271.65 \pm 67.34$ & 0.569 \\
\hline${ }^{1} \mathrm{TSH}$ & $2.01 \pm 1.26$ & $1.77 \pm 1.12$ & $1.92 \pm 1.20$ & 0.451 \\
\hline
\end{tabular}

Table 3. Comparison of normal and abnormal values of CRP, uric acid, MPV, and RDW according to groups

\begin{tabular}{|c|c|c|c|c|c|}
\hline & & $\begin{array}{c}\text { Grup } 1(n=39) \\
n(\%)\end{array}$ & $\begin{array}{c}\text { Grup } 2(n=23) \\
n(\%)\end{array}$ & $\begin{array}{c}\text { Total }(n=62) \\
n(\%)\end{array}$ & $\mathbf{p}$ \\
\hline${ }^{2}$ Uric acid (blood) & $\begin{array}{l}\text { Normal } \\
\text { Abnormal }\end{array}$ & $\begin{array}{c}38(97.4) \\
1(2.6)\end{array}$ & $\begin{array}{c}23(100) \\
0(0)\end{array}$ & $\begin{array}{c}61(98.4) \\
1(1.6)\end{array}$ & 1.000 \\
\hline Uric acid (urine) & $\begin{array}{l}\text { Normal } \\
\text { Abnormal }\end{array}$ & $\begin{array}{l}25(64.1) \\
14(35.9)\end{array}$ & $\begin{array}{c}20(87) \\
3(13)\end{array}$ & $\begin{array}{l}45(72.6) \\
17(27.4)\end{array}$ & 0.098 \\
\hline${ }^{1} \mathrm{CRP}$ & $\begin{array}{l}\text { Normal } \\
\text { Abnormal }\end{array}$ & $\begin{array}{l}20(51.3) \\
19(48.7)\end{array}$ & $\begin{array}{l}14(60.9) \\
9(39.1)\end{array}$ & $\begin{array}{l}34(54.8) \\
28(45.2)\end{array}$ & 0.639 \\
\hline${ }^{1} \mathrm{RDW}$ & $\begin{array}{l}\text { Normal } \\
\text { Abnormal }\end{array}$ & $\begin{array}{l}27(69.2) \\
12(30.8)\end{array}$ & $\begin{array}{c}19(82.6) \\
4(17.4)\end{array}$ & $\begin{array}{l}46(74.2) \\
16(25.8)\end{array}$ & 0.388 \\
\hline${ }^{1} \mathrm{MPV}$ & $\begin{array}{l}\text { Normal } \\
\text { Abnormal }\end{array}$ & $\begin{array}{l}28(71.8) \\
11(28.2)\end{array}$ & $\begin{array}{l}13(56.5) \\
10(43.5)\end{array}$ & $\begin{array}{l}41(66.1) \\
21(33.9)\end{array}$ & 0.342 \\
\hline
\end{tabular}

reference intervals of the parameters. These values are $0-5$ $\mathrm{mg} / \mathrm{L}$ for CRP, 11.5-14.5 RU for RDW, 3.7-9.2 mg/dL for serum uric acid, $37-92 \mathrm{mg} / \mathrm{dL}$ for spot urine uric acid, and
In the evaluation of the effects of SBP, DBP, triglyceride, and cholesterol, which were found to be significant in univariate analyses, on the disease through logistic regression analysis, the model was revealed to be highly significant; Negelkerke 
Table 4. The sensitivity of CRP, uric acid, MPV and RDW values in predicting the disease

\begin{tabular}{|c|c|c|c|c|c|}
\hline & Sensitivity & Specificity & $\begin{array}{c}\text { Positive } \\
\text { predictive value }\end{array}$ & $\begin{array}{c}\text { Negative } \\
\text { predictive value }\end{array}$ & Accuracy \\
\hline Uric acid (blood) & 0.00 & 97.44 & 0.00 & 62.30 & 61.29 \\
\hline Uric acid (urine) & 39.13 & 51.28 & 32.14 & 58.82 & 46.77 \\
\hline CRP & 33.33 & 94.87 & 33.33 & 94.87 & 90.48 \\
\hline RDW & 43.48 & 71.79 & 47.62 & 68.29 & 61.29 \\
\hline MPV & 3.03 & 95.00 & 50.00 & 37.25 & 37.74 \\
\hline
\end{tabular}

Table 5. Relationship among parameters in the patient group (group 2)

\begin{tabular}{|c|c|c|c|c|c|c|c|c|c|c|c|c|}
\hline \multirow[b]{2}{*}{ Patient } & \multicolumn{2}{|c|}{ BMI } & \multicolumn{2}{|c|}{ GFR } & \multicolumn{2}{|c|}{$\begin{array}{l}\text { Blood uric } \\
\text { acid }\end{array}$} & \multicolumn{2}{|c|}{$\begin{array}{l}\text { Spot urine } \\
\text { uric acid }\end{array}$} & \multicolumn{2}{|c|}{ CRP } & \multicolumn{2}{|c|}{ RDW } \\
\hline & $\mathbf{r}$ & $\mathbf{p}$ & $\mathbf{r}$ & $\mathbf{p}$ & $\mathbf{r}$ & $\mathbf{p}$ & $\mathbf{r}$ & $\mathbf{p}$ & $\mathbf{r}$ & $\mathbf{p}$ & $\mathbf{r}$ & $\mathbf{p}$ \\
\hline BMI & - & - & - & - & - & - & - & - & - & - & - & - \\
\hline GFR & 0.081 & 0.712 & - & - & - & - & - & - & - & - & - & - \\
\hline Blood uric acid & 0.002 & 0.992 & -0.179 & 0.414 & - & - & - & - & - & - & - & - \\
\hline Spot urine uric acid & -0.019 & 0.932 & -0.038 & 0.862 & -0.231 & 0.288 & - & - & - & - & - & - \\
\hline CRP & 0.260 & 0.232 & -0.283 & 0.191 & 0.052 & 0.813 & 0.260 & 0.230 & - & - & - & - \\
\hline RDW & -0.004 & 0.984 & -0.697 & $0.001 * *$ & 0.194 & 0.374 & -0.143 & 0.514 & 0.419 & $0.047 *$ & - & - \\
\hline MPV & 0.060 & 0.786 & 0.362 & 0.089 & -0.127 & 0.563 & 0.118 & 0.592 & -0.119 & 0.589 & -0.446 & $0.033^{*}$ \\
\hline
\end{tabular}

R-square value was 0.228 , and the model's coefficient of determination was at a good level $(74.2 \%)$. However, the effect of any parameter on the model was not found to be statistically significant.

While there was no significant correlation among GFR, RDW, MPV, urine and blood uric acid, and CRP values in Group 1 $(\mathrm{p}=0.001)$, a statistically significant negative correlation was found between GFR and RDW in Group 2 ( $p<0.01)$. Similarly, there was a statistically significant positive correlation between CRP and RDW and a negative correlation between RDW and MPV in Group 2 ( $\mathrm{p}=0.047 ; \mathrm{p}<0.05, \mathrm{p}=0.033$; $\mathrm{p}<0.05$, respectively) (Table 5).

\section{Discussion}

As in many diseases, strict control of blood pressure and early detection of cardiovascular complications are highly important in the prevention of HT's cardiovascular complications. For this purpose, many serum and urine parameters should be investigated. In this study, the relationship among laboratory parameters that were investigated in 62 patients without any chronic disease except HT was examined in two groups as those developing and not developing cardiovascular complications.

As expected in our study, SBP and DBP were detected to be significant risk factors in terms of the development of cardiovascular complications in hypertensive patients. Banach et al. (16) found the rate of cardiovascular disease as $5.4 \%$ and reported a linear relationship between blood pressure and cardiovascular disease and all-cause mortality risk in different age groups.

In our study, there was no significant relationship between patient and control groups with regard to CRP, serum and spot urine uric acid, RDW, and MPV values, which are reported to be associated with different cardiovascular diseases in many studies. In literature, there are conflicting data on this issue. Hung et al. (17) reported that coronary artery spasm was observed with significantly low hsCRP values in patients having diabetes or HT. Kraus et al. (18) stated that hsCRP was not a distinct criterion for the determination of cardiovascular disease risk because of ethnicity, gender, obesity, and comorbidities. Gouri et al. (19) found a relationship between high uric acid level and diabetes and HT in 45 hemodialysis patients and they detected cardiovascular diseases to be associated with low serum uric acid level. Ofori et al. (20) reported a significant relationship between serum uric acid levels and target organ damage in hypertensive patients. Durante et al. (21) specified that uric acid was protective against the progression of HT. While Tsioufis et al. (22) found serum uric acid level to be significantly associated with body mass index, SBP, and urine albumin excretion, they revealed no relationship with left ventricular hypertrophy. In our country, Ozcan et al. (23) and Tanindi et al. (24) found a significant correlation between RDW and non-dipper HT and SBP and DBP. Yavuzkir et 
al. (25) reported no significant relationship between left ventricular mass index and MPV. On the other hand, Karabacak et al. (26) found MPV to be independently correlated with diabetes and SBP. Bulur et al. (27) detected no significant relationship between left ventricular mass index and albuminuria levels and MPV.

In many studies that were conducted for early prediction of targeted organ damage, hsCRP, RDW, and serum uric acid levels were generally found to be significant. The parameters examined in our study were also detected to be insignificant in the prediction of cardiovascular complications. In general, MPV and findings related to serum uric acid level found by some researchers were consistent with our study, but the findings on CRP and RDW were inconsistent. Insignificant result on CRP might have been due to that normal CRP levels were evaluated instead of hsCRP in our study, whereas hsCRP was used in other studies. We could not evaluate the effects of patient treatments for HT and/or comorbid conditions on all parameters because of insufficient data records, which can be considered as a limitation of our study.

\section{Conclusion}

In this study investigating the efficiency of serum and spot urine uric acid, CRP, RDW, and MPV levels in the prediction of cardiovascular diseases in essential hypertensive patients, no relationship was detected between the levels of serum and spot urine uric acid and MPV, CRP, and RDW, which display a close correlation with cardiovascular diseases. It was concluded that these parameters were not predictive for cardiovascular diseases. However, more comprehensive and prospective further studies are needed for reaching an acceptable result on this issue.

Ethics Committee Approval: Ethics committee approval was received for this study from local ethics committee.

Informed Consent: Informed consent was obtained from patients who participated in this study.

Peer-review: Externally peer-reviewed.

Author Contributions: Concept - D.S.; Design - F.K.; Supervision - D.S., İ.Ş.; Funding - Y.N.K.; Materials - Y.N.K.; Data Collection and/or Processing - Y.N.K.; Analysis and/or Interpretation - Y.N.K., D.Ş., İ.Ş.; Literature Review - Y.N.K., D.Ş.; Writing - Y.N.K., D.Ş.; Critical Review - İ.Ş.

Conflict of Interest: No conflict of interest was declared by the authors.

Financial Disclosure: The authors declared that this study has received no financial support

\section{References}

1. Mazzali M, Hughes J, Kim YG, Jefferson JA, Kang DH, Gordon KL, et al. Elevated uric acid increases blood pressure in the rat by a novel crystalindependent mechanism. Hypertension 2001; 38: 1101-6. [CrossRef]

2. Soletsky B, Feig DI. Uric acid causes pre-hypertension in obese adolescents. Hypertension 2012; 60: 1148-56. [CrossRef]
3. Feig DI, Soletsky B, Johnson RJ. Effect of allopurinol on blood pressure of adolescents with newly diagnosed essential hypertension: a randomized trial. JAMA 2008; 300: 924-32. [CrossRef]

4. Goicoechea M, de Vinuesa SG, Verdalles U, Ruiz-Caro C, Ampuero J, Rincon A, et al. Effect of allopurinol in chronic kidney disease progression and cardiovascular risk. Clin J Am Soc Nephrol 2010; 5: 1388-93. [CrossRef]

5. Wilson PW. Established risk factors and coronary artery disease: the Framingham Study. Am J Hypertens 1994; 7: 7S-12S.

6. Feig DI, Kang DH, Johnson RJ. Uric acid and cardiovascular risk. N Engl J Med 2008; 359: 1811-21. [CrossRef]

7. Alderman M, Aiyer KJV. Uric Acid: Role in Cardiovascular Disease and Effects of Losartan. Curr Med Res Opin 2004; 20: 369-79. [CrossRef]

8. Mundal HH, Hjemdahl P, Gjesdal K. Acute effects of low dose nicotine gum on platelet function in non-smoking hypertensive and normotensive men. Eur J Clin Pharmacol 1995; 47: 411-6. [CrossRef]

9. Senaran H, Ileri M, Altinbas A, Koşar A, Yetkin E, Oztürk M, et al. Thrombopoietin and mean platelet volume in coronary artery disease. Clin Cardiol 2001; 24: 405-8. [CrossRef]

10. Erne P, Wardle J, Sanders K, Lewis SM, Maseri A. Mean Platelet Volume and Size Distribution and Their Sensitivity to Agonist in Patients with Coronary Artery Disease and Congestive Heart Failure. Thromb Haemostas 1988; 59: 259-63.

11. Pizzulli L, Yang A, Martin JF, Luderitz B. Changes in platelet size and count in unstable angina compared to stable angina or non-cardiac chest pain. EurHeart J 1998; 19: 80-4. [CrossRef]

12. Zwaka TP, Hombach V, Torzewski J. C-reactive protein mediated low density lipoprotein uptake by macrophage: Implication for atherosclerosis. Circulation 2001; 103: 1194-7. [CrossRef]

13. Dodson PM, Shine B. Retinal vein occlusion: C-reactive protein arterial hypertension. Acta Ophtalmol 1984; 62: 123-30. [CrossRef]

14. Wen Y. High red blood cell distribution width is closely associated with risk of carotid artery atherosclerosis in patients with hypertension. Exp Clin Cardiol. 2010; 15: 37-40.

15. Levey AS, Stevens LA, Schmid CH, Zhang YL, Castro AF, Feldman $\mathrm{HI}$, et al. A new equation to estimate glomerular filtration rate. Ann Intern Med 2009; 150: 604-12. [CrossRef]

16. Banach M, Bromfield S, Howard G, Howard VJ, Zanchetti A, Aronow WS, et al. Association of systolic blood pressure levels with cardiovascular events and all-causemortality among older adults taking antihypertensive medication. Int J Cardiol 2014; 176: 219-26. [CrossRef]

17. Hung MJ, Hsu KH, Hu WS, Chang NC, Hung MY. C-reactive protein for predicting prognosis and its gender-specific associations with diabetes mellitus and hypertension in the development of coronary arteryspasm. PLoSOne 2013; 8: e77655. [CrossRef]

18. Kraus VB, Stabler TV, Luta G, Renner JB, Dragomir AD, Jordan JM. Interpretation of serum C-reactive protein (CRP) levels for cardiovascular disease risk is complicated by race, pulmonary disease, body mass index, gender, and osteoarthritis. Osteoarthritis Cartilage 2007; 15: 966-71. [CrossRef]

19. Gouri A, Dekaken A, Bentorki AA, Touaref A, Yakhlef A, Koicem N. Serum uric acid level and cardiovascular risks in hemodialysis patients: an Algerian cohort study. Clin Lab 2014; 60: 751-8.

20. Ofori SN, Odia OJ. Serum uric acid and target organ damage in essential hypertension. Asc Health Risk Manag 2014; 10: 253-61. [CrossRef]

21. Durante P, Chávez M, Pérez M, Romero F, Rivera F. Effect of uric acid on hypertension progression in spontaneously hypertensive rats. Life Sci 2010; 86: 957-64. [CrossRef]

22. Tsioufis C, Chatzis D, Vezali E, Dimitriadis K, Antoniadis D, Zervoudaki A, et al. The controversial role of serum uric acid in essential hypertension: relationships with indices of target organ damage. J Hum Hypertens 2005; 19: 211-7. [CrossRef]

23. Ozcan F, Turak O, Durak A, Işleyen A, Uçar F, Giniş Z, et al. Red cell distribution width and inflammation in patients with non-dipper hypertension. Blood Press 2013; 22: 80-5. [CrossRef] 
24. Tanindi A, Topal FE, Topal F, Celik B. Red cell distribution width in patients with prehypertension and hypertension. Blood Press 2012; 21: 177-81. [CrossRef]

25. Yavuzkir MF, Kurtoğlu E, Yilmaz M, Korkmaz H, Cakmak T, Dogdu $\mathrm{O}$, et al. Relationship between mean platelet volume elevation and left ventricular mass index in hypertensive patients. J Int Med Res 2014; 42: 781-7. [CrossRef]
26. Karabacak M, Dogan A, Turkdogan AK, Kapci M, Duman A, Akpinar O. Mean platelet volume is increased in patients with hypertensive crises. Platelets 2014; 25: 423-6. [CrossRef]

27. Bulur S, Önder HI, Aslantas Y, Ekinozu I, Kiliç AÇ, Yalcin S, et al. Relation between indices of end-organ damage and mean platelet volume in hypertensive patients. Blood Coagul Fibrinolysis 2012; 23: 367-9. [CrossRef] 